\title{
The Effects of Methallibure on Conspecific Visual Reinforcement, Social Display Frequency, and Spawning in the Paradise Fish, Macropodus opercularis (L.) Belontiidae
}

\author{
ROGER E. DAVIS, MARK MITCHELL AND LYNMARIE DOLSON \\ The Mental Health Research Institute and the Neurosciences Laboratory \\ The University of Michigan, Ann Arbor, MI 48109
}

(Received 17 October 1975)

\begin{abstract}
DAVIS, R. E., M. MITCHELL AND L. DOLSON. The effects of methallibure on conspecific visual reinforcement, social display frequency, and spawning in the Paradise Fish, Macropodus opercularis, (L.) Belontiidae. PHYSIOL. BEHAV. 17(1) 47--52, 1976. - Pretrial intramuscular administration of the antigonadotropin, methallibure suppressed operant responding for conspecific visual stimulation. Four administrations of the drug during an 11 day period did not noticeably impair gametogenesis. Oral administration of methallibure for 5 weeks resulted in a decrease in frequency of lateral display, but not frontal display, in a $10 \mathrm{~min}$ trial with a live stimulus male, and a decrease in the gonadosomatic index and fertility but not spawning readiness. The possibility that methallibure disrupts catecholamine synthesis is discussed.
\end{abstract} Methallibure Visualstimulation Antigonadotropin Operant responding Catecholamine synthesis
Gametogenesis

TELEOST gonad function can be suppressed by administration of methallibure (Imperial Chemical Industries product No. 33,828), a nonsteroidal inhibitor of pituitary gonadotropin, which has been investigated in mammals $[3,24]$ and fishes $[2,14]$. In fishes, methallibure administration by feeding, immersion, and injection has been used to elucidate the effects of steroids and gonadotropin on gonad structure and gametogenesis, steroidogenesis, and behavior $[2,5,13,14,20,25,27,28,29]$ in various species. The frequency of social displays and fighting in male sunfish is reduced when methallibure is periodically administered by intramuscular injection $[10,18]$. Whether spawning is blocked by doses of methallibure which result in gonad atrophy has apparently not been examined. Our experiments were conducted to investigate the effects of methallibure on operant responding for conspecific visual stimulation, social display frequency, and spawning behavior and fertility.

\section{EXPERIMENT 1: OPERANT BEHAVIOR}

The first experiment was to determine whether methallibure has immediate effects on operant behavior. Kramer [18] found that intermale social behavior is reduced following only several IM administration of methallibure, $0.2 \mathrm{mg} / \mathrm{gBW}$, which are given at intervals of several days. We adopted an operant conditioning task in which fish received a $40 \mathrm{sec}$ period of visual stimulation from a conspecific as a reward for swimming through a small ring [6]. When each swim-through response is reinforced, the operant rate is highest during the first several hr of the acquisition session and then it decreases [23]. If methallibure has immediate effects which decrease the readiness of the individual to approach a conspecific, then the initial surge of responding in an acquisition session might be decreased by administering the drug prior to the session. The effect of the drug was examined in 4 successive acquisition trials, or sessions of continuous reinforcement, which were separated by two day intervals of extinction, or nonreinforcement.

\section{METHOD AND PROCEDURE}

Six male paradise fish, Macropodus opercularis, 4.3-5.9 $\mathrm{cm}$ body length, and $3.1-4.7 \mathrm{~g}$, and 6 females, $4.0-4.3 \mathrm{~cm}$, and $2.1-3.0 \mathrm{~g}$, were obtained from domesticated stock in Florida. The fish were placed in individual isolation tanks [6] for 2-5 weeks prior to the experiment. Water temperatures were $24^{\circ}-26^{\circ} \mathrm{C}$. The daily cycle of diffuse natural light was augmented by a $14: 10 \mathrm{hr}, \mathrm{L}: \mathrm{D}$ cycle of daylight fluorescent light. Visual contact between fish in adjacent tanks was blocked by opaque partitions to enhance the fish's reactivity [8]. Several days following

\footnotetext{
${ }^{1}$ We gratefully acknowledge the assistance of Jessie Shelby, Robin Dibner and Gertrude Calloway in conducting these experiments.
} 
isolation, fish were placed in individual operant conditioning tanks to shape the swim-through response.

\section{Operant Conditioning Tank}

A 57 liter glass tank, $30 \times 60 \mathrm{~cm}$, was filled with $22 \mathrm{~cm}$ of continuous flowing, fresh $24^{\circ}-26^{\circ} \mathrm{C}$ water at 400 $\mathrm{ml} / \mathrm{min}$ (Fig. 1). The tank was illuminated by a 25 watt incandescent lamp during the daily light period, and by very dim light from a small, filtered panel lamp above the manipulandum during the dark period. The interior walls were covered with opaque sheets of non-mirroring plastic. A vertical sliding door in the center of the one wall covered a $12 \times 14 \mathrm{~cm}$ window to the stimulus fish compartment. A linear actuator (Skinner Polynoid) raised and lowered the door when visual reward was to be presented.

The manipulandum was a $2.5 \mathrm{~cm}$ dia. plastic ring (Fig. 1). An infrared beam from a photodetector (Scientific Technology Inc.), in an adjoining water-tight compartment, crossed the ring through a slit to a mirror and back to the photodetector. The mirror was covered with a red filter. When the fish entered the ring, interrupting the beam, the door to the stimulus compartment opened for $40 \mathrm{sec}$. Fish could open the door by swimming through the ring toward or away from the stimulus compartment door. Swimthrough responses which occurred when the door was opened did not result in additional openings. A response opened the door only when the fish had been out of the ring for a period of $5 \mathrm{sec}$. The photodetector circuit was interfaced to a PDP-8F digital computer which registered responses, presented the $40 \mathrm{sec}$ visual reinforcements, and compiled mean response frequencies. Responses which resulted in an opening of the door and responses which occurred while the door was opened were tallied separately.

\section{Response Shaping and the Acquisition Ratio}

The shaping procedure consisted of successive $24 \mathrm{hr}$ periods of extinction, acquisition, and extinction, following which the fish were returned to the isolation tanks. The 24 hr periods started and ended at $1000 \mathrm{hr}, 4 \mathrm{hr}$ after the onset of the daily light period at $0600 \mathrm{hr}$. In extinction, each swim-through response resulted in a $40 \mathrm{sec}$ presentation of the empty stimulus compartment. In acquisition, a paradise fish of the same sex as the subject was presented in the stimulus compartment. The reinforcing effect of the conspecific stimulation was determined for each fish. The number of responses that the fish made during the acquisition period divided by the number of responses which were made the preceding period of extinction was denoted as the acquisition ratio. Fish which showed ratios of 2 or more were used as subjects.

The effect of methallibure on the ratio was examined in four $23 \mathrm{hr}$ acquisition trials which followed an initial $23 \mathrm{hr}$ period of extinction; two $23 \mathrm{hr}$ periods of extinction intervened between successive acquisition trials. The $23 \mathrm{hr}$ periods began at $1100 \mathrm{hr}$ and ended at $1000 \mathrm{hr}$ the following day. During the daily 1 hr time-out (1000-1100 hr) the fish was briefly handled then fed Tetramin, and swim-through responses were not recorded or reinforced. In the time-out prior to an acquisition trial, the fish were administered intramuscular methallibure or saline. When a period of extinction followed the time-out, the fish were handled but not injected.

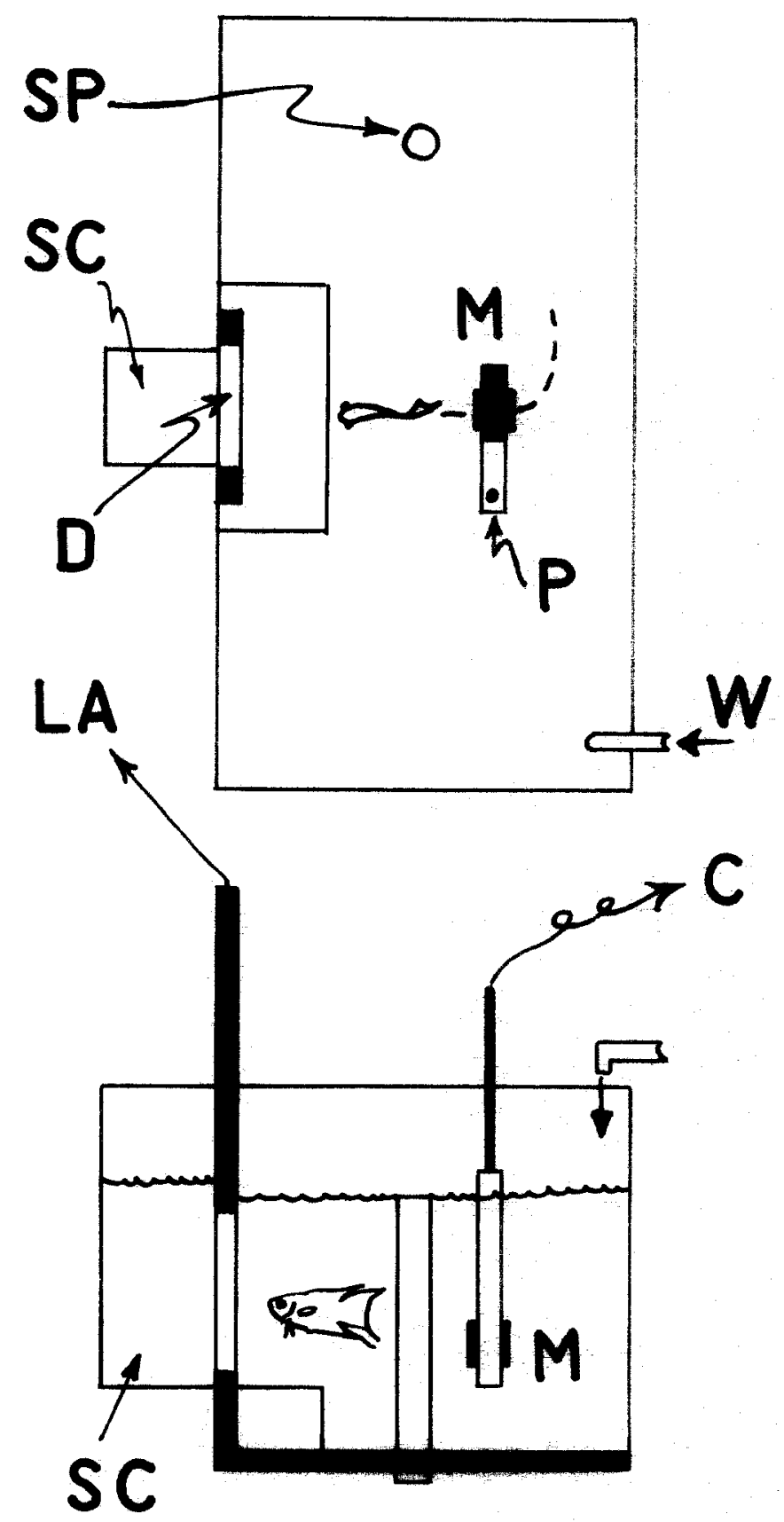

FIG. 1. Operant conditioning tank as viewed from the top (above) and the end (below): $\mathrm{C}$, to computer, $\mathrm{D}$, door covering the Fishes view of the stimulus compartment, $L A$, to linear actuator operating the door, M, swim-through manipulandum, P, photodetector, SC, stimulus compartment, SP, standpipe drain, W, continuously flowing water. The diagram is approximately to scale; the fish is slightly oversize.

\section{Drug Administration}

Three males and females received $1 \mathrm{mg} / \mathrm{g} \mathrm{bW}$ of methallibure suspended in saline with Tween 80 [13] within $1 \mathrm{hr}$ prior to each acquisition period. The remaining 3 males and females received $10 \mu \mathrm{l} / \mathrm{gBW}$ of saline with Tween 80 . The injections were made with $100 \mu 1$ Hamilton syringe with a $27 \mathrm{ga}$. needle. The fish were restrained in a polyethylene bag on a cushioned surface. The needle was 
inserted through the bag into the epaxial muscle mass dorsal to the coelom. Successive injections were made on opposite sides of the body. The number of responses which the fish made during an acquisition trial was divided by the number in the initial extinction period to obtain the acquisition ratio. The mean ratios were contrasted in analyses of variance (ANOVA) which were carried out on an IBM 370 computer.

\section{Gonad Histology}

Following the experiment the fish was killed in ice water. Then the gonads were removed, fixed in Bouins, embedded in paraffin and cut in $8 \mathrm{~mm}$ sections. The percentage of oocytes in 3 stages of vitellogenesis [7] was determined in random $1 \mathrm{~mm}^{2}$ areas on 3 sections of the ovary as an index of gonadotropin inhibition [13]. Ten cross-sections of seminiferous lobules near the middle of the testes were examined to determine the mean dia. $[2,13]$ and the ratio of spermatogonia and primary spermatocytes to spermatozoa in the lobule lumin.

\section{RESULTS}

A 3-way ANOVA of the mean acquisition ratios in Table 1 reveals a significant Drug effect $(F(1,8)=15.54, p<0.01)$ and Sex effect $(F=6.77, p<0.05)$ but no significant Trials effect or interactions $(\mathrm{F}<1)$. Nearly all the responses occurred during the $14 \mathrm{hr}$ light period. The fish were strongly light-active and quiescent in dim light. Few swim-through responses occurred during the $40 \mathrm{sec}$ rewards and they were excluded from the acquisition ratio determinations. In the extinction sessions, prior to the acquisition session, the mean hourly rate ranged from $3.3-4.8$, and the rate did not vary significantly for drug and non-drug males and females.

\section{TABLE 1}

EFFECTS OF PRETRIAL INTRAMUSCULAR METHALLIBURE ON THE ACQUISITION RATIO OF MALE AND FEMALE PARADISE FISH. EACH VALUE IS A MEAN RATIO FOR THREE FISH IN FOUR TRIALS

\begin{tabular}{lcc}
\hline Subject & Saline & $\begin{array}{c}\text { Methallibure } \\
(1 \mathrm{mg} / \mathrm{gBW})\end{array}$ \\
\hline Male & 4.02 & 1.69 \\
Female & 5.87 & 3.16 \\
\hline
\end{tabular}

Fish variably darkened within several hr following administration of methallibure. Their color patterns lacked the brillance which is typical of paradise fish in agonistic encounters. The effect tended to wane by the following day.

The frequency of oocytes in various stages of vitellogenesis was not significantly affected by the methallibure (Table 2). The mean maximum cross-section of the seminiferous lobules was $0.08 \mathrm{~mm}$ for methallibure and salinetreated males, and the ratio of spermatozoa and primary spermatocytes was 1.4 and 1.5 , respectively. Thus no differences in gonad function or structure were detected which would indicate that gonadotropin was suppressed by methalibure.

\section{TABLE 2}

THE PERCENTAGE OF OOCYTES IN VARIOUS STAGES OF VITELLOGENESIS FOLLOWING 4 ADMINISTRATIONS OF INTRAMUSCULAR METHALLIBURE ( $1 \mathrm{mg} / \mathrm{gBW}$ ) OR SALINE IN 11 DAYS

\begin{tabular}{lcccc}
\hline \multicolumn{5}{c}{ Oocyte Stage } \\
\hline Treatment & $\mathrm{N}$ & $\mathrm{I}$ & $\mathrm{II}$ & III \\
Saline & 3 & $62 \%$ & $14 \%$ & $24 \%$ \\
Methallibure & 3 & $68 \%$ & $17 \%$ & $16 \%$ \\
Student'st & $<1$ & 1.11 & 2.14 \\
& & $\mathrm{~ns}$ & $\mathrm{~ns}$ & $\mathrm{~ns}$ \\
\hline
\end{tabular}

\section{DISCUSSION}

The attenuation of the operant rate following pretrial administration of methallibure is consistent with the hypothesis that the drug has immediate physiological effects which decrease the readiness of a fish to approach a conspecific. It remains to be shown whether the slight suppression of operant behavior is linked to a decrease in gonadotropic hormone secretion. Hoar [12] and Baggerman [1] have proposed that gonadotropin facilitates social fighting behavior in nonreproductive sticklebacks, and that testicular secretions maintain the aggressive behaviors of reproductive individuals. However, we have no evidence that the methallibure inhibited gonadotropin. The dose we used was approximately 5 times that which Kramer [18] found to decrease social display behavior in sunfish.

Investigations in fishes have revealed that little if any impairment of gonad structure or gametogenesis occurs in less than 2 weeks of continuous methallibure administration [14,29]. Breton, Jalabert and Billard [2] kept male goldfish immersed in $2 \mathrm{ppm}$ methallibure and found that plasma gonadotropin briefly increased within the first 2 days. A significant decrease below the baseline level did not occur until 2 weeks following immersion with the drug, and gametogenesis inhibition was correspondingly delayed. Methallibure can produce a relatively immediate decrease in gonadotropin in mammals [9] but whether similar, immediate inhibitory effects occur in fishes has yet to be determined.

\section{EXPERIMENT 2: SOCIAL DISPLAY FREQUENCY}

Domesticated paradise fish are continuously reproductive in the laboratory. Social displays, chasing, biting and butting occur at relatively uniform frequencies throughout the year. The sexes perform similar lateral and frontal displays, though lateral display occurs more frequently in males than in females $[6,7]$. The present experiment was to determine whether a prolonged application of methallibure which results in testicular atrophy in males also results in a decrease in display frequency.

To obtain testicular atrophy in fish methallibure is commonly administered by immersing the fish in a periodically replenished suspension of the drug. Since the drug has to be applied for a period of weeks, the immersion method is advantageous. It is convenient and the fish need not be handled. In contrast, IM injection entails netting, holding and needle insertions which increase the probability of tissue damage and infection. We found immersion to be ineffective in paradise fish (see below) and, as an alternative, presented methallibure in daily feedings. 


\section{METHOD AND PROCEDURE}

Four groups of 6 , experimentally naive males, 4.7-5.6 $\mathrm{cm}$ and $3.3-5.8 \mathrm{~g}$, were kept in individual isolation tanks for 5 weeks. The fish in adjacent tanks could see each other through the clear glass walls. Individuals received an average of $30 \mathrm{mg}$ dry food daily. Three groups received experimental diets $\mathrm{A}, \mathrm{B}$ and $\mathrm{C}$, which contained $0.003,0.03$ and $0.3 \mathrm{mg}$ methallibure $/ 30 \mathrm{mg}$ of dry food. The other group received a control diet.

\section{Diets}

The diets were prepared from Tetramin staple conditioning food with gum tragacanth, $0.03 \mathrm{~g} / \mathrm{g}$ food, added as a binder. Methallibure was dissolved in acetone, mixed with powdered food to form a slurry which was then dried over low heat and stored at $5^{\circ} \mathrm{C}$. The control diet was mixed with acetone without methallibure. The diets were moistened with clean water to form compact pellets which the fish could engulf in one to several bites. Pellets not eaten within $30-60$ min were removed from the tank.

\section{Display Tank}

The readiness to perform social displays to a live, stimulus male was measured in two $10 \mathrm{~min}$ trials, one following 3 weeks of feeding, the other at the end of the 5 week period. The male was netted from the home tank, carried in a small container to the experimental room, and poured into the neutral zone of the display tank (Fig. 2) which was previously described [8]. The $10 \mathrm{~min}$ trial started when the male swam into the stimulus zone and oriented toward the stimulus male which was previously placed in the stimulus compartment. The frequency of the fish's lateral and frontal displays [17] were registered with a manual keyboard and an Esterline Angus recorder. Lateral displays were recorded when the fish fully extended its caudal, anal, and dorsal fins with its body parallel, or nearly so, to the window of the stimulus compartment. Frontal display was recorded when the fish faced the stimulus fish and spread its gill covers. The identity of the fish was unknown to the observer. A fully blind testing procedure was precluded, however, since high doses of methallibure result in discoloration of the fish's skin. Following the second trial, the testes were removed to determine the gonadosomatic index, G.S.I. $=100 \times($ testes wt. $/$ body wt. $)$

\section{RESULTS}

The mean frequencies of lateral and frontal display in
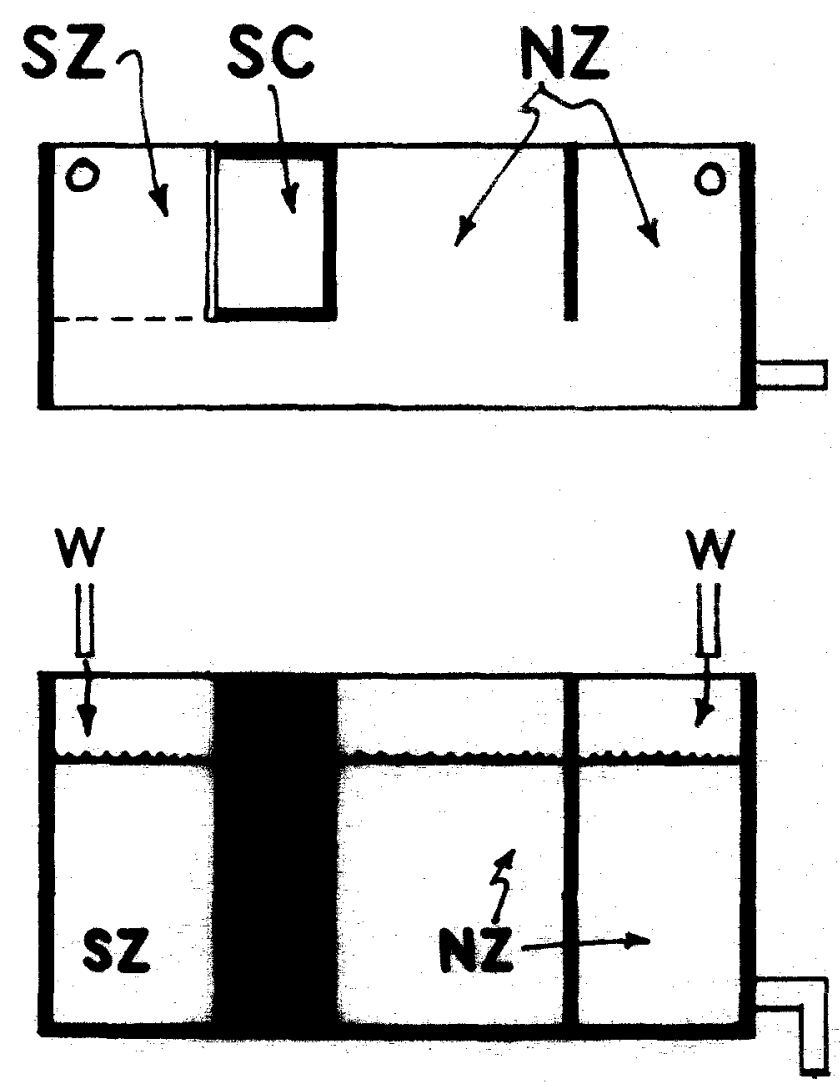

FIG. 2. The $15 \times 40 \times 20 \mathrm{~cm}$ high display tank as viewed from the top (above) and the front (below). NZ, neutral zone, SC, stimulus compartment, SZ, stimulus zone, $W$, continuously flowing water, $500 \mathrm{ml} / \mathrm{min} ; 24^{\circ}-26^{\circ} \mathrm{C}$.

the trials following 3 and 5 weeks of methallibure feeding are presented in Table 3. Frontal display did not vary significantly with the dose of the drug, $(\mathrm{F}<1)$ though it did decrease somewhat with increased duration of treatment $(F(1,20)=5.33, p<0.03)$ and showed a strong Dose $x$ Duration interaction $(F(3,20)=12.25, p<0.001)$

The origin of the interaction is clear in the data for Trials 1 and 2 (Table 2). Lateral display did not vary with the dose in Trial 1. The drug effect appeared in Trial 2 in which the controls showed a higher lateral display frequency then the A-diet males $(t=10.56, p<0.009)$, the B-diet males $(t=5.21, p<0.04)$ and the $C$-diet males $(t=$ $22.95, p<0.0007)$. In addition the ( diet males showed at

TABLE 3

EFFECTS OF PROLONGED ORAL ADMINISTRATION METHALLIBURE ON THE FREQUENCY OF LATERAL (LD) AND FRONTAL (FD) DISPLAYS IN A 10 MIN TRIAL WITH A LIVE STIMULUS MALE

\begin{tabular}{lccccccc}
\hline $\begin{array}{l}\text { Methallibure } \\
\text { Diet/day }\end{array}$ & \multicolumn{2}{c}{ Trial 1 } & \multicolumn{2}{c}{ Trial 2 } & \multicolumn{2}{c}{ Trial 2 minus 1 } & G.S.1 \\
\hline CD & FD & LD & FD & I.D & FD & \\
\hline Control & 24.3 & 19.7 & 44.8 & 12.3 & +20.5 & -7.3 & 0.16 \\
(A) $0.003 \mathrm{mg}$ & 16.8 & 17.7 & 18.3 & 9.8 & +1.5 & -7.8 & 0.13 \\
(B) $0.03 \mathrm{mg}$ & 28.7 & 17.2 & 24.0 & 14.3 & -4.7 & -2.8 & 71.16 \\
(C) $0.03 \mathrm{mg}$ & 24.2 & 12.3 & 7.3 & 9.7 & -16.8 & -2.7 & 0.08 \\
F ratio & 1.41 & $<1$ & 8.86 & -1 & 12.25 & $<1$ & 12.66 \\
& $\mathrm{~ns}$ & $\mathrm{~ns}$ & $p<.0006$ & $\mathrm{~ns}$ & $p<.0001$ & $\mathrm{n}$ & $p<000$ \\
\hline
\end{tabular}


lower mean lateral display frequency than the A- and B-diet males $(t=11.35$ and $12.78, p<0.0005)$. The mean display frequencies for A and B-diet males were not significantly different. Thus all doses of methallibure suppressed lateral displays but the C-diet was the most effective.

The mean G.S.I. was decreased only in the males which received diet $C$ (Table 3 ). Independent $t$-tests reveal no significant difference among the control and the $A$ and B-diet males, whereas the C-diet males differed from the controls $(t=59.62, p<0.0001)$, A-diet males $(t=7.53$, $p<0.02)$ and B-diet males $(t=101.2, p<0.0001)$.

The males which received diet $C$ were less brilliantly colored than the other males. Following a week or 2 of feeding, red-orange pigments disappeared and the body assumed a leaden, blue-green coloring. The vertical stripes of malanophores, which are usually pronounced in untreated males, were diffuse or lacking.

\section{DISCUSSION}

Lateral display frequency was attenuated following 5 weeks but not 3 weeks of oral administration of methallibure. Prior to the trial at 3 weeks the C-diet males were discolored and they seemed less active than the males on other diets, and we were surprised that the frequency of displays was not suppressed. It is interesting that the drug affected lateral display but not frontal display, since lateral display occurs more frequently in male than in female paradise fish $[6,7]$. The selective suppression of lateral display, in conjunction with the atrophy of the gonad, suggests that testicular androgens may play a role in maintaining lateral display readiness. Methalliburesuppressed sunfish $[10,18]$ show increased social displays following an injection of exogenous androgen.

The suppression of social display in paradise fish is consistent with the results obtained in the sunfish, Lepomis gibbosus, by Kramer [18] but it was slower. Detailed comparisons are precluded by differences in experimental procedure. Given a higher dose of methallibure, comparable to that administered in Experiment 1, paradise fish might show decreased display readiness in a shorter period of time. The maximum oral dose was limited by the tendency of the fish to refuse to eat Tetramin with more than one percent methallibure (Diet C). The fish also would not reliably eat more than $30-50 \mathrm{mg}$ of Tetramin daily without waste. Kramer [34] fed sunfish doses of methallibure up to $0.65 \mathrm{mg} / \mathrm{g} \mathrm{BW} /$ day. Diet $\mathrm{C}$, expressed in terms of average body weight $(4.2 \mathrm{~g})$, provided $0.05 \mathrm{mg} / \mathrm{g} \mathrm{BW} / \mathrm{day}$. While lower doses of the drug, in Diets $A$ and $B$, resulted in an intermediate suppression of lateral display, in relation to the control fish which showed increased display readiness, diet $\mathrm{C}$ decreased display readiness below the initial level.

Though immersion in suspensions of $1-2$ ppm methallibure has antigonadotropic effects in various teleost fishes, labyrinthine fishes, such as Macropodus, may prove to be an exception. We found no effect of methallibure in males which were kept for 8 weeks in tanks to which $1 \mathrm{ppm}$ of the drug was added every other day. Display frequency and the G.S.l. were not decreased. The drug may not have been efficiently absorbed. Paradise fish are obligate air breathers and they show only intermittent branchial movements. Water containing $1 \mathrm{ppm}$ methallibure smells foul to humans and may be an aversive chemical stimulus to the fish. The air breathing habit has been interpreted as an adaptation to low oxygen levels in stagnant water [21]. It is interesting to speculate that air breathing also protects fish from dissolved toxic substances.

\section{EXPERIMENT 3: SPAWNING AND FERTILITY}

The atrophy of the testes produced by Diet $C$ in Experiment 2 indicated that gonadotropic inhibition can be achieved in paradise fish through oral administration of methallibure. The reduced testes and the correlated decrease in social display behavior suggested that mating and fertility would be impaired. Spawning by methallibure suppressed males was investigated in the present experiment.

\section{METHOD AND PROCEDURE}

Two groups of 6 , experimentally naive males, 4.8-5.7 $\mathrm{cm}$, and $3.2-5.5 \mathrm{~g}$, were administered control diet and diet-C for 5 weeks. Each male was then placed in a spawning tank with a female until spawning or for a maximum of 5 consecutive days during which the pair were fed Tetramin without methallibure. The tank was inspected daily to determine the time of spawning. When a pair spawned, the egg-laden foamnest was dipped from the tank and stored at $24^{\circ}-26^{\circ} \mathrm{C}$. In $1-2$ days, dead eggs and live embryos were counted. The male's fertility was expressed as the percent live eggs, or $100 \times$ (No. live/No. dead + No. live) The G. S. I. was determined immediately following the spawning trial.

\section{RESULTS}

Five of the 6 control males and 4 of the $6 \mathrm{C}$-diet males spawned in the 5 day trial. One C-diet male did not spawn and one was not mated because it showed incipient bacterial sepsilesis and excessive lethargy. Methallibure may or may not have facilitated the infection; paradise fish which are not experimentally treated develop similar infections and may rapidly weaken and die. The mean fertility per cent was 37 for the C-diet males and 95 for the controls. No values overlapped between the 2 groups. One C-diet male showed $85 \%$ fertility, another was fully infertile and the other 2 showed low fertility. The mean G.S.I. values were 0.07 and 0.15 , for the $C$-diet and control group, respectively, and there was no overlap between the 2 groups.

\section{DISCUSSION}

Daily feedings of methallibure for 5 weeks resulted in atrophy of the testes and impairment of fertility but the treatment did not appear to interfere with spawning. Removal of methallibure from the male's diet could have resulted in recovery of gonadotropin secretion during the 5 day spawning trial. The return of normal coloration suggested that some effects of the drug were reversed in a few days. Hyder [15] showed that following 5 weeks of methallibure treatment, spermatogenesis in Tilapia resumes within 1 week. A similar recovery of testes function in paradise fish might account for the fact that of the 4 C-diet males which spawned 3 released viable sperm. Spawning in paradise fish (in preparation), as in various other teleosts [19], appears to be unimpaired by surgical castration indicating that sexual behavior is not dependent upon testicular androgen. Whether pituitary gonadotropin maintains spawning readiness remains to be determined. 


\section{Speculation on the Mode of Action of Methallibure}

The physiology effects of methallibure and, specifically, the mechanisms by which the drug inhibits gonadotropin are unknown. Brain implants in mammals indicate that methallibure acts at the level of the hypothalamus and not the pituitary [22]. In goldfish, methallibure reduces plasma but not pituitary gonadotropin suggesting that the drug inhibits gonadotropin releasing factor [2]. Methallibure might act by suppressing norepinephrine which has been implicated in regulating gonadotropin release $[4,16]$. The possibility that methallibure can disrupt catecholamine synthesis is suggested by its structural affinity with Disulfiram and U-14,624 which are potenl in vivo inhibitors of dopamine- $\beta$-hydroxylase $[11,26]$. The similarity can be seen in the abbreviated formulas: Methallibure, R-NH.CS.NH.CS.NH-R' (24]. Disulfiram R -N.CS.S.S.CS.N-R, and its metabolite "DDC" or diethyldithiocarbamate, R,R N.CS.S [11], and U 14,624, R -.NH.CS.NH-R' [26]. The behavioral and gonadal effects of methallibure may thus originate directly or indirectly from a suppression of catecholamine synthesis

\section{REFERENCES}

1. Baggerman, B. Hormonal control of reproductive and parental behavior in fishes. In: Perspectives in Endocrinology, edited by E. J. Barrington and C. B. Jorgensen. New York: Academic Press, 1968, pp. 351-404.

2. Breton, B., B. Jalabert and R. Billard. Pituitary and plasma gonadotropin levels and spermatogenesis in the goldfish Carassius auratus after methallibure treatment. J. Endocr. 59; 415-420, 1973.

3. Brown, P. S. Observations on a dithiocarbamoylhydrazine as an inhibitor of pituitary gonadotrophic activity. J. Endocr. 26: 425-436, 1963.

4. Brown, P. S. and L. Fawke. Effects of reserpine, p-chlorophenylalanine, a-methyltyrosine, thymoxamine, or methallibure on pituitary FSH in male rats. J. Reprod. Fert. 28: $167-175,1972$

5. Calvo, J. and E. R. Morriconi. Accion del methallibure y de las gonadotrofinas exogenas sobre el testiculo de Jenynsia lineata (Teleostei). Acta physiol. Latinoam. 22: 212-217, 1972.

6. Davis, R. E., C. Harris and J. Shelby. Sex differences in aggressivity and the effects of social isolation in the anabantoid fish, Macropodus opercularis. Behav. Biol. 11: 497-509, 1974.

7. Davis, R. E., and J. Kassel. The ontogeny of agonistic behavior and the onset of sexual maturation in the paradise fish, Macropodus opercularis (Linnaeus), Behav. Biol. 14: 31-39. 1975.

8. Davis, R. E. Readiness to display in the paradise fish Macropodus opercularis, (L.), Belontiidae: The problem of general and specific effects of social isolation. Behav. Biol. 15: (In press).

9. Deis, R, and N. Vermouth. Antiovulatory effect of I.C.I. 33828 without affecting prolactin release in normal rats. Neuroendocrinology 13: 351-356, 1973.

10. Feidler, K. Hormonale Kontrolle des Verhaltens bei Fischen Fortschr. Zool. 22: 268-309, 1974.

11. Goldstein, $M$. Inhibition of norepinephrine biosynthesis at the dopamine- $\beta$-hydroxylation stage. Pharmac. Rev. 18: 77- 82. 1966.

12. Hoar, W. S. Comparative Physiology: Hormones and re production in fishes. Ann. Rev. Physiol. 27: 51-70, 1965.

13. Hoar, W. S., J. Wiebe and E. H. Wai. Inhibition of the pituitary gonadotropic activity of fishes by a dithiocarbamoylhydrazine derivative (I.C.I. 33, 828) 1967. Gen. comp. Endocr. 8: $101-109,1967$.

14. Hyder, M. Endocrine regulation of reproduction in Tilapia. Gen. comp. Endocr. Suppl. 3: 729-740, 1972.

15. Hyder, M., V. S. Aruna, A. V. Shah, C. M. Campbell and S Dadzie. Methallibure studies on Tilapia. II. Effect of Tilapia pituitary homogenate (TPH), human chorionic gonadotropin (HCG) and testosterone proprionate (TP) on the testes of methallibure-treated Tilapia nigra. Gen. comp. Endocr. 23: $245-255,1974$.
16. Kalra, P. S. and S. M. McCann. Involvement of catecholamines in feedback mechanisms. Prog. Brain Res. 39: 185 --198, 1973.

17. Kassel, J, and R. E. Davis. Early behavioral experience and adult social behavior in the paradise fish, Macropodus oper. cularis (L.) Behav. Biol. 15: (In press).

18. Kramer, B. Behavioral effects of an antigonadotropin, of sexual hormones, and of psychopharmaka in the pumpkinseed sun fish, Lepomis gibbosus (Centrachidae). Experientia 28(10): $1195-1196,1972$.

19. Liley, N. R. Hormones and reproductive behavior in tishes. In Fish Physiology, edited by W. S. Hoat and D. J. Randall. New York: Academic Press, 1969 , vol. 3, pp. 73116

20. Mackay, N. J. Effects of methallibure and thiourea on gametogenesis in the firetail gudgeon, Hypeleotris galit. Gen comp. Endocr. 20: 221-235, 1973.

21. Machowicz, P. and J. C. Gray. Branchial circulation in Macropodus opercularis L.. Ohio 1 Sct 55(3): 129 136, 1955.

22. Malven, P. V., J. A. Clemens and C. H. Sawyer. Inhibition of ovarian compensatory hypertrophy in the rat by intrahypothalamic implantation of methallibure. Endocrinology 88: $511-513,1971$

23. Melvin, K. B. and J. E. Anson. Image-induced aggressive display: Reinforcement in the paradise fish. Psychol. Rec. 20: $225-228,1970$

24. Paget, G. E., A. L. Walpole and D. N. Richardson. Non-steroid inhibitors of pituitary gonadotropic function. Nature 192: $1191-1192,1961$.

25. Pandey, S. Effects of methallibure on the testes and secondary sex characters of the adult and juvemile guppy Poecilia reticulata Peters. Biol. Reprod. 2: $239.244,1970$.

26. Pletcher, A. The impact of monoamine research on druy development. In: Frontiers in Catecholamine Research, edited by E. Usdin and S. H. Snyder. New York: Pergamon Press, 1973, pp. 27-37.

27. Van den Hurk, R. and H. Van de Kant. The effect of methyl testosterone, 11-Ketotestosterone and methallibure on gonadotropic cells, Leydig cells, spermatogenesis and the epithelium of the intratesticular efferent duct system of the juvenile male black Molly (Mollienisia latipinna). Proc. Kon. Ned. C. 78(3) $275-285,1975$.

28. Van den Hurk, R. and H. Van de Kant. The effect of methallibure and methyl testosterone on gonadotropic celts, Leydig cells and the intratesticular efferent duct system of the adult male black molly (Mollienisia latipinna). Proc. Kon. Ned. C. $78(3): 265-274,1975$

29. Wiebe, J. P. Endocrine control of spermatogenesis and oogenesis in the viviparous sea perch Cymatogaster aggregata Gibbons. Gen comp. Endocr. 12: 267 275, 1968. 